\title{
The effect of dust components and contaminants on the performance of photovoltaic for the four regions in Iraq: a practical study
}

\author{
Miqdam T. Chaichan ${ }^{1,}$, Hussein A. Kazem ${ }^{2,3}$, Ali H.A. Al-Waeli ${ }^{3}$, and Kamaruzzaman Sopian ${ }^{3}$ \\ ${ }^{1}$ Energy and Renewable Energies Technology Center, University of Technology, Baghdad, Iraq \\ 2 Sohar University, PO Box 44, PCI 311 Sohar, Oman \\ 3 Solar Energy Research Institute, Universiti Kebangsaan Malaysia, 43600 Bangi, Selangor, Malaysia
}

Received: 3 December 2019 / Accepted: 10 December 2019

\begin{abstract}
The accumulation of dust on the surface of the solar cell causes a clear decrease in its performance. The present study has led to investigate the impact of pollution and dust of four different Iraq regions of different conditions on solar cells performance. The areas studied were Baghdad, an agricultural area in Mahmoodia, the Karbala-Najaf desert road, and the city of Fao. The components of dust samples were examined from the areas mentioned and a high percentage of silica was found, which shows the impact of the desert in the Iraqi dust. In Baghdad and Mahmoodia dust samples, clear proportions of clay and silt minerals were found that can be traced back to the fertile valley of Mesopotamia. Significant percentages of particulate matter (PM), lead and sulfur were found in Fao and Baghdad dust samples indicating high contamination by fossil fuel combustion emissions. Practical experiments were carried out to measure the current, voltages, and power of a solar cell, and a clear reduction in these parameter values was measured. From the types of the components of dust samples, the study suggested suitable periodic cleaning period and cleaning methods for each type of dust.
\end{abstract}

\section{Introduction}

Global energy demand is growing at an ever-increasing rate, owing to the rising number of people worldwide and the progress in the well-being of societies and industry. The bulk of the energy produced globally (up to $97 \%$ ) is from fossil sources [1]. This type of fuel emits dangerous pollutants that have caused catastrophic phenomena on the planet such as increased global warming and climate change [2]. The continued dependence on fossil fuels is offset by several global events to reduce this dependence and shift towards renewable energies such as solar energy [3]. Solar energy is a renewable energy source that includes in wind, bioenergy, hydroelectricity, and geothermal energy [4]. Renewable energies play an important role in the growing evolution towards reducing carbon in the atmosphere, helping to reduce greenhouse gas pollutants [5].

A solar cell is a simple device that can convert sunlight into electrical energy. Methods that convert solar energy into electricity prevent the generation of pollutants from combustion processes and reduce global warming. The high price of hydrocarbon fuels, together with the apparent

\footnotetext{
* e-mail: 20185@uotechnology.edu.iq
}

decrease in solar cell prices, has caused high demand for solar cell systems, whereas in the past, solar cells were considered suitable for specific applications only in remote and remote areas. At present, many countries are interested in this technology because of its simplicity and ease of installation [6]. Solar cells or Photovoltaic (PV) modules are also highly flexible, as plants can be constructed in plains, mountains and even seas. Solar cells operate in external atmospheres directly connected with sharp fluctuations in wind speed, temperatures, solar radiation intensity, humidity, and dust accumulation on them [7]. Some of these factors cause a significant reduction in the capacity exiting the cell system [8].

The accumulation of dust causes a significant reduction in the intensity of solar radiation reaching the surface of the PV module and results in a marked deterioration in the conversion of solar energy into electricity [9]. The location of the PV modules determines the amount of pollution and dust accumulated on the unit [10]. The rate of dust accumulated on the surface of a solar cell depends on several factors associated with each site, the most important of which are the concentrations of suspended particles in the atmosphere, particle size, and atmospheric conditions [11]. Accumulated dust concentrations vary not only by location but also by the time of exposure to external conditions [12]. 
The particle size distribution of accumulated dust has an important and direct effect on the degradation of solar cell efficiency (PV) [13]. The size of the accumulated dust particles plays a role in the reflection, dispersion, and absorption of incident light on PV modules. They also play an important role in their interaction with wind speed. Large particles volatilize and attach to the air even at moderate wind speeds while small particles tend to hold together and with the PV module surface [14]. Accumulation of fine dust particles causes more degradation in PV performance than larger particles. If they are compared on the basis of a constant mass of dust, fine dust particles have a larger surface area and are more uniformly distributed than larger particles. Small molecules also have less surface roughness than large dust particles, reducing the spaces between the particles through which light passes [15]. Reference [16] studied the distribution of dust particle sizes accumulated on the surface of a PV and found that most of the dust accumulated had sizes ranging from 1 to $50 \mu \mathrm{m}$ [17].

Studies of dust accumulated on PV surfaces have identified 15 types of dust elements such as ash, limestone, red soil, calcium carbonate, silica, and sand have a significant impact on the performance of PV modules. Reference [18], after studying the accumulated dust from six different locations in Oman, confirmed the effect of the physical properties of the accumulated dust on the performance of PV modules. Other studies have confirmed that sufficient information on the chemical composition of accumulated dust particles would be useful in determining the type of cleaning method to be used for the PV surface $[19,20]$.

A proper understanding of the physical and chemical properties of accumulated dust is essential to determine the appropriate cleaning technique to reduce the effects of dust accumulation on PV. The chemical composition and particle size distribution determine the method of dust interaction with the PV surface and thus determines the cleaning method to be used for each case [21]. Many researchers have relied on cleaning PV with pressurized water to mitigate the effects of dust accumulation. Reference [22] after collecting data for one year on climate conditions and the production of PV modules for six systems in six Omani cities has proven that three of the cities (Liwa, Sohar, and Muscat) are exposed to more accumulated pollution and dust than the rest of the group. By examining the physical and chemical properties of the accumulated dust, it was found that the most prominent pollutants accumulated on the surface of PV modules are particulate matter (PM) resulting from the burning of oil and natural gas in power plants, aluminum smelters in the industrial city of Sohar, in addition to the emission of vehicles with large numbers in the capital Muscat. This result confirms the intervention of human activities clearly in the amount and quality of dust and pollutants accumulated on PV. For the other three cities (Suwaiq, Khaboura, and Shinas), researchers found that the accumulation of dust and pollutants on PV modules was limited, because these cities were far from industrial zones and low traffic. From the study of the physical properties and chemical components of this dust, it was found that the maximization of silicon, which means dust with natural components and the interference of human activities in its components, was very limited. The researchers used several known and locally available methods to clean the tested PV modules after dust was allowed to accumulate for a month. The results showed that the use of water to clean PV units in Shinas, Al Khaboura, and Al-Souq cities gave acceptable results, while the results of this method of cleaning were unacceptable in Liwa, Sohar and Muscat due to the accumulation of substances such as PM and many chemical compounds. In these cities, the study showed that the use of solutions containing sodium gives good cleaning results for PV units.

Reference [23] collected several samples of dust accumulated on PV modules normally at different exposure times in Doha, Qatar. Dust samples were analyzed using several analysis methods. The results showed a difference in the quality and quantity of dust accumulated during winter and summer. The size of the accumulated dust particles decreases as the exposure time increases and reaches almost constant values when the PV module is exposed to long exposure times. The researchers found that calcium is the most abundant component of accumulated dust, followed by silicon, iron, magnesium, aluminum, calcite, dolomite and quartz. The study concluded that the rates of halite and quartz in the contents of dust increase with the occurrence of storms dependent on the direction of the wind. The dust particles accumulate with increasing exposure time.

Reference [24] reviewed the geographical characteristics, topography, and weather conditions in different regions of Iraq. A thorough review of human activities and activities that have caused desertification to increase in the country over the past century has also been reviewed. One of the most important manifestations of the increase in desertification in Iraq is a large contraction of the green areas in the Mesopotamia Valley accompanied by a significant increase in the number and frequency of sand and dust storms in it. The study focused on the causes of dust escalation, its components, and risk on the use and spread of PV in energy production. The study found that dust samples had high levels of clay minerals, so elements such as muscovite, chlorite and kaolinite were found in high percentages. The most tested samples have clear concentrations of silt of $2-62 \mu \mathrm{m}$ and clay particles with a size not exceeding $2 \mu \mathrm{m}$. In urban areas of Iraq, pollution from power plants, oil refineries, traffic, and the heavy use of diesel generators in cities is a source of heavy metals such as lead, nick, cadmium, chromium and the most dangerous of sulfur compounds in house and the streets dust $[25,26]$.

Dust contamination depends largely on the location and geographic location of the PV system installation, so it is difficult to identify such cases using a predetermined model $[27,28]$. Therefore, the present study aims to clarify the effect of the accumulation of dust pollutants on the PV surface and the impact on the performance. This impact depends on the basic elements of the accumulated dust, whose components vary from region to region. The study was conducted in various areas of Iraq, which is characterized by topographic diversity with high pollution sources in and around cities. What distinguishes this study from others is that it chose four sites that differ in their 
environmental conditions completely from each other and compared the effect of dust and accumulated air pollutants on the PV panels and determined the treatment for each type of dust in a practical and experimental way.

\section{Methodology}

\subsection{Dust collection}

In the first part of the study, the accumulated dust was collected on a horizontal glass surface during the spring from $15 / 3 / 2019$ to $15 / 5 / 2019$ from four different locations. Station 1 is located in Baghdad. Site 1 (University of Technology) is an urban area with modern buildings and high traffic in addition to the traffic concentrated throughout the day. Site 2 (located on the outskirts of the city of Mahmoodia, $30 \mathrm{~km}$ south of Baghdad), where the study area is agricultural land irrigated by artesian wells (with a high proportion of salts). The third site is located on the desert road in the area linking the cities of Karbala and Najaf and is one of the newly deserted lands despite its proximity to the Tigris and Euphrates rivers due to government and popular neglect. The fourth site is located in the city of Fao in southern Iraq, supervising the Arabian Gulf and surrounded by the salted lake, an area that dries out sea water leaving high concentrations of natural salt.

These four sites were chosen as they represent several different environments, including urban (Baghdad), agriculture (Mahmoudiyah), desert (Karbala-Najaf), and marine (Fao). These environments are a summary of the geographical and topographical conditions in Iraq, and the variation in them makes the installation of $\mathrm{PV}$ stations in any of them need a separate study of environmental conditions on this site. The choice of four sites with different environmental conditions gives clarity in the comparison of their individual products.

Daily readings of solar radiation, air temperature, relative humidity, and wind speed were taken in the study areas using a weather station type WS-STD1 (made in UK) with uncertainty ranging from $1.03 \%$ for Najaf-Karbala station to $2.87 \%$ for Fao station. Uncertainty rates in the study are less than $5 \%$, which makes the reliability of the results satisfactory and geometrically acceptable.

\subsection{Analyze dust collection samples}

In the second part of the study, the collected dust components were analyzed for the four study areas using $\mathrm{X}$-ray diffraction device (XRD) type (Bruker D8 Advance), and X-ray radiation (XRF) type (Horiba XGT-7200) to evaluate the quantity and quality of dust particles collected. These devices were calibrated in the Central Organization for Standardization and Quality Control in Baghdad and found the uncertainty of the XRD device does not exceed $0.35 \%$, while the XRF device uncertainty was $0.46 \%$. Dust samples were also examined to determine the distribution of the sizes and measurements of the accumulated dust particles using a set of sieves with specific measurements. The minimum sieve size used was $63 \mu \mathrm{m}$, and this measurement did not cover nanoscale dust
Table 1. The used sieves sizes.

\begin{tabular}{lll}
\hline SR no. & Sieve size $(\mu \mathrm{m})$ & Sieve no. \\
\hline 1 & 3350 & 6 \\
2 & 2360 & 8 \\
3 & 2000 & 10 \\
4 & 600 & 30 \\
5 & 425 & 40 \\
6 & 300 & 50 \\
7 & 212 & 70 \\
8 & 150 & 100 \\
9 & 75 & 200 \\
10 & 63 & 230 \\
\hline
\end{tabular}

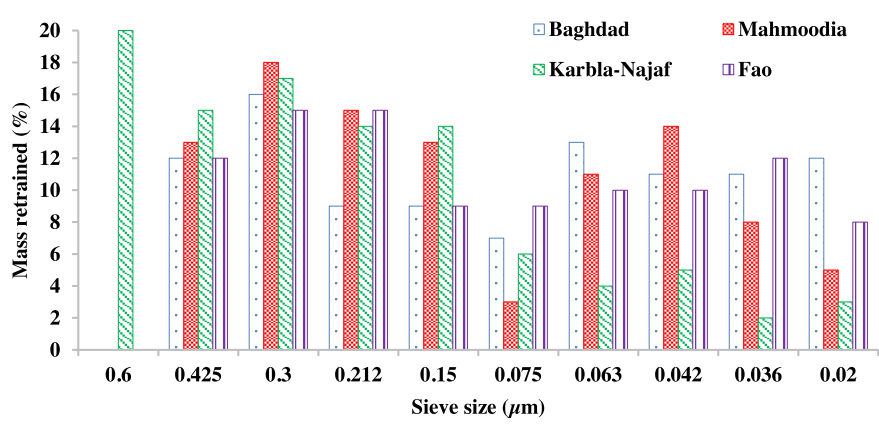

Fig. 1. Dust grain size analysis for the studied locations.

particles, so a hydrometer test was used. This test was used for grain sizes lower than $63 \mu \mathrm{m}$. Experiments were performed using sieves and hydrometer scale according to BS 1377-2: 1990: 9.3. Table 1 shows the measurements of the sieves used. Figure 1 shows an analysis of the dust volume of the four sites.

\subsection{Laboratory devices}

In the third part of the study, specific amounts of dust collected were deposited on a PV module. Table 2 lists its specifications, and the effect of each dust type on PV performance was studied in detail. The study was carried out in the laboratory to control the climatic conditions and limit the variables only to the change of dust type and concentration. Therefore, a light of $500 \mathrm{~W} / \mathrm{m}^{2}$, a laboratory temperature of $25^{\circ} \mathrm{C}, 40 \% \mathrm{RH}$, and air movement at a speed not exceeding $0.1 \mathrm{~m} / \mathrm{s}$ was used. The Sun Simulator (SPIRE 5600SLP) was used to measure the I-V of the PV module, the device uncertainty is $0.78 \%$. The weight of the dust particles was made with a precise electronic weighing type (EJ6I0-E) and an uncertainty of $0.28 \%$.

\subsection{Tests procedure}

After processing and weighing the dust samples, they are scattered on the PV cell and subjected to shaking using a vibrator at a shaking speed of 60 shakes/min for five minutes to ensure a uniform spread of dust particles on the 
Table 2. The used PV modules specification.

\begin{tabular}{ll}
\hline Maximum power (Pmax) & $105 \mathrm{~W}$ \\
Open circuit voltage (Voc) & $20 \mathrm{~V}$ \\
Short circuit current (Isc) & $5.3 \mathrm{~V}$ \\
Max. power voltage(Vmp) & $18.2 \mathrm{~V}$ \\
Max. power current (Imp) & $6.27 \mathrm{~A}$ \\
Cell temperature (Tc) & $25{ }^{\circ} \mathrm{C}$ \\
Irradiation(Ga) & $1000 \mathrm{~W} / \mathrm{m}^{2}$ \\
PV length & $1.43 \mathrm{~m}$ \\
PV width & $0.63 \mathrm{~m}$ \\
PV area & $0.9 \mathrm{~m}^{2}$ \\
\hline
\end{tabular}

PV module. The board, then, was left for half an hour to give dust particles time to settle. The PV is then exposed to the lamps and the voltage and current measurements are taken.

\section{Discussion and conclusions}

\subsection{Weather conditions}

The performance of the PV is affected by the accumulation of dust on its surface. There are many environmental and topographic factors that interfere with the formation of dust particles and the variability of these molecules, whether in chemical and physical properties, phase or sorting. Factors (such as air temperature, relative humidity, and wind speed) also play a key role in determining the concentrations of suspended and dispersed dust in the atmosphere and the method of accumulation on the surface of the PV module $[29,30]$.

Reference [11] explained in detail the impact of different weather factors on the performance of the solar cell to the conditions of Iraq, and the reader interested refer to the reference above. However, it is worth mentioning that the four areas were chosen in the study diverge. Baghdad, for example, is the capital of Iraq, which is packed with a large population and high traffic, three power stations, giant refinery, thousands of factories, and thousands of electrical generators. The second study area (Mahmoodia) lies within orchards scattered over a large area in the fertile Mesopotamia Valley or the rest of it, its weather conditions are almost similar to Baghdad. The plantings are watered with artesian wells and many diesel pumps are used. The third study area (Karbala-Najaf road) is a desert area par excellence but close to the Tigris and Euphrates rivers and agricultural area is therefore affected by desert climate and high number of dust and sand storms. The fourth study area (Fao) is surrounded by saline, an area that the Gulf water enters during the tide and away from it through the carrots. The remaining water evaporates due to high temperatures leaving natural salts. The climate in this region is high temperature most days of the year, and the relative humidity is high exceeding $90 \%$ most of the year as well.

\subsection{Dust grains composition}

Table 3 lists the main Iraqi dust components for the four stations. The differences between the components of the dust particles of the four sites are obvious. For example, Baghdad station has a high percentage of silicon resulting from the desert of Anbar adjacent to the city. Also, the proportions of aluminum, iron, calcium and magnesium, which are the main components of the mud, silt, bentonite and muscovite clear concentrations because the Tigris River breaks this city and its green areas wide. Engine exhaust pollutants, such as generators, vehicles, power plants and Doura refinery, also result in high concentrations of PM and sulfur. Concentrations of lead in dust also result from the exhaust of gasoline engines that use high-lead gasoline.

Mahmoodia station dust's components analysis reveals less silicon because the station is laid in agricultural area, however, the clay and mud components are larger than Baghdad dust. As this area is relatively far from urban areas and the traffic is low, the PM and S concentrations in the dust are from diesel generators that operate pumps and generate electricity for farmer houses. The lead concentration, although lower than Baghdad, but these concentrations in such areas give a negative sign on the hazardous air pollution of Baghdad, which transfer to tens of kilometers. Karbla-Najaf station dust has high percentage of silicon and less concentration of calcium, iron and aluminum, as the area is desert, but the little concentrations found are due to the agriculture areas near this desert station. PM and sulfur concentrations are due to high traffic between these two governorates. Fao station dust manifests high concentration of salty grains and PM, $\mathrm{Pb}$ and sulfur. The salt grains sources are the salty land adjacent to the city and the gulf salty water. PM and sulfur resulted from the polluted air of Basra governorate because of drilling, production, and transportation of oil process, which are conducted near this station.

\subsection{Dust grain sizes analysis}

Dust particles vary in size from station to station, mostly in precise sizes, because they are from desert sources and combustion pollutants. For example, a high proportion of the Baghdad dust particles are less than 20 nano meter, and this is due to the fact that the bulk of it comes from desert in addition to the result from the burning of fossil fuels. The same can be described for the Fao station with the difference that a large part of the nanostructure dust source is fossil fuel combustion as well as salt particles. The remaining two stations Mahmoodia and Karbala-Najaf have less concentrations of nano- sized dust and higher concentration of micro dust and this is good as cleaning the latter is much easier, especially if it is silicon. Apart from the health hazards of the nanostructure dust, its deposition on the PV module surface and its cohesion with the surface make the process of disinformation high and reduces the sunlight and the difficulty of cleaning the surface of the PV cell [31]. 
Table 3. Dust components in the studied samples.

\begin{tabular}{lllll}
\hline Component & \multicolumn{3}{c}{ Location } \\
\cline { 2 - 5 } & Baghdad (\%) & Mahmoodia (\%) & Karbla-Najaf (\%) & Foa (\%) \\
\hline $\mathrm{SiO}_{2}$ & 56.17 & 53.62 & 65.15 & 52.54 \\
$\mathrm{CaO}$ & 3.39 & 3.90 & 2.56 & 1.66 \\
$\mathrm{Al}_{2} \mathrm{O}_{3}$ & 5.47 & 5.16 & 3.37 & 2.71 \\
$\mathrm{Fe}_{2} \mathrm{O}_{3}$ & 3.24 & 3.77 & 2.40 & 2.51 \\
$\mathrm{MgO}$ & 2.38 & 2.92 & 1.95 & 1.47 \\
$\mathrm{NaCl}$ & 3.57 & 3.27 & 2.98 & 9.96 \\
$\mathrm{~K}_{2} \mathrm{O}$ & 3.12 & 3.74 & 2.69 & 3.54 \\
$\mathrm{TiO}_{2}$ & 2.17 & 3.50 & 1.42 & 0.98 \\
$\mathrm{SO}_{3}$ & 1.04 & 1.63 & 1.44 & 1.13 \\
$\mathrm{MnO}_{2}$ & 2.69 & 1.44 & 1.77 & 1.47 \\
$\mathrm{Cr}_{2} \mathrm{O}_{3}$ & 2.33 & 2.52 & 1.23 & 1.32 \\
$\mathrm{SrO}$ & 2.81 & 1.05 & 1.62 & 1.44 \\
$\mathrm{NiO}$ & 1.52 & 2.35 & 0.89 & 1.93 \\
$\mathrm{SiO}_{2}$ & 1.37 & 1.72 & 1.58 & 1.42 \\
$\mathrm{PM}^{\mathrm{Gypsum}}$ & 3.4 & 1.11 & 2.06 & 7.84 \\
$\mathrm{~Pb}$ & 2.35 & 0.93 & 1.29 & 1.33 \\
$\mathrm{~S}$ & 0.87 & 0.85 & 1.42 & 3.21 \\
\hline
\end{tabular}

\subsection{Dust effect on PV parameters}

Figures 2-4 show the impact of accumulated dust on PV current (Fig. 2), voltage (Fig. 3) and the resulting power (Fig. 4). Dust was distributed on the PV surface at constant weight ratios from $20 \mathrm{~g} / \mathrm{m}^{2}$ to $100 \mathrm{~g} / \mathrm{m}^{2}$. The accumulated dust causes a decrease in the intensity of the radiation reaching the $\mathrm{PV}$ module. As a result, reduced current generated, the increased concentration of dust increases the amount of current losses and these losses vary depending on the type of dust per plant. Figure 2 shows that when the accumulated dust increases from 0 to $100 \mathrm{~g} / \mathrm{m}^{2}$, the current decreases by $19.50 \%, 15.20 \%, 20.50 \%$, and $25.66 \%$ for Baghdad, Mahmoodia, Karbla-Najaf and Fao stations, respectively. The lowest current losses were for Mahmudiya and Karbla-Najaf stations while Fao stations ranked the worst result. These results show the effect of dust components generated by the current.

Figure 3 represents the ratios of $\mathrm{I}_{\text {plluted }} / \mathrm{I}_{\text {clean }}$ for the tested dusts. Mahmoodia, where dust has lower PM and salt and more clay and mud components gave the best results of generated current. Here, it must be noticed that the tests were conducted inside the laboratory at standard temperature $25^{\circ} \mathrm{C}$ and humidity $40 \%$. For Fao station dust, salt binds to the surface of the cell and forms a thin layer that prevents the passage of rays, in addition to the PM particles that dyed the region's dust in black.

Figure 3 shows the impact of dust accumulation on a PV module voltage for the studied dust types. The voltage reduced with increasing dust deposition quantity, but the reduction varies from station to another. The significant reduction appears when Fao station dust is deposited and the reduction rate increases with increasing the deposition

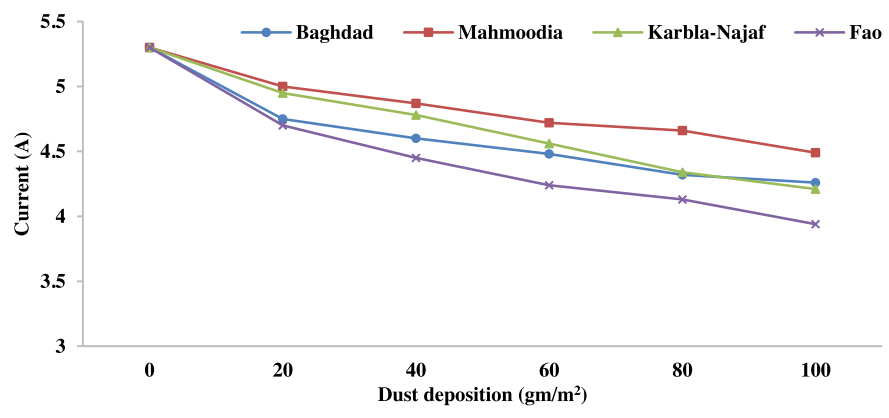

Fig. 2. Current losses due to dust accumulation on PV.

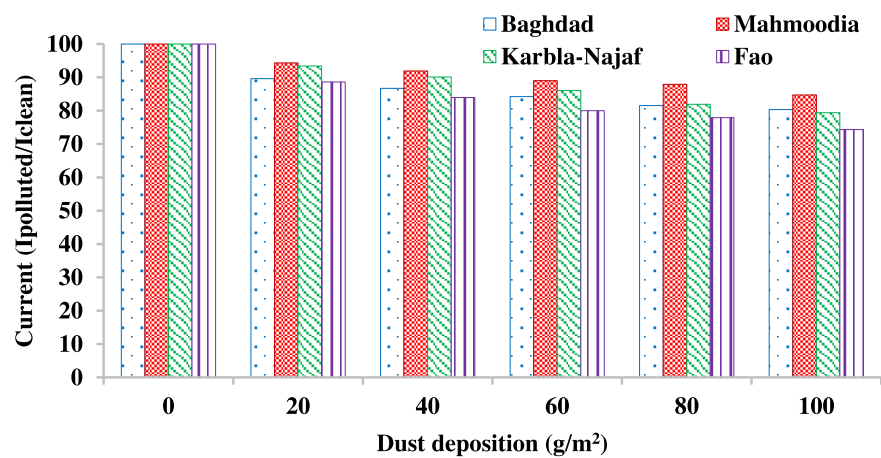

Fig. 3. Dust accumulation effect on $I_{\text {polluted }} / I_{\text {clean }}$ ratio.

quantities. The voltage was reduced by $23.5 \%, 10.85 \%$, $19.45 \%$, and $26.1 \%$ for Baghdad, Mahmoodia, KarblaNajaf and Fao stations, respectively when dust was deposited from 0 to $100 \mathrm{~g} / \mathrm{m}^{2}$. 


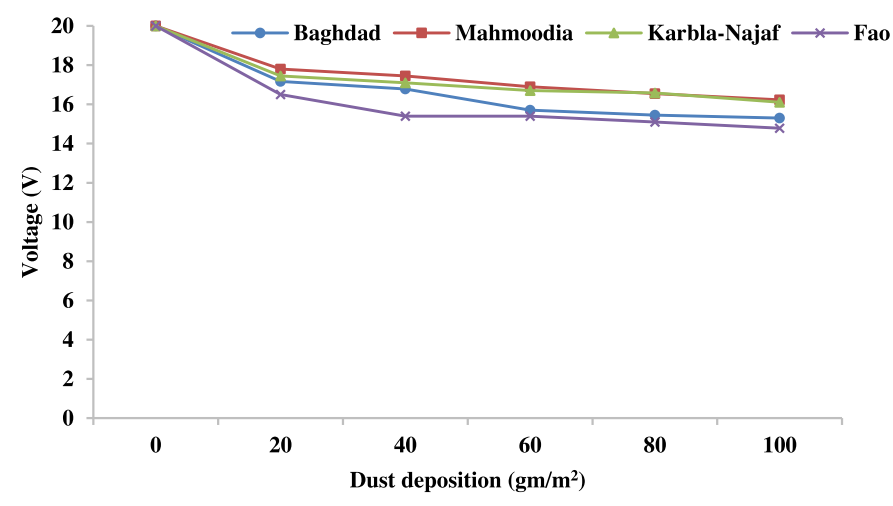

Fig. 4. Voltage reduction due to dust accumulation on PV surface for the tested dust types.

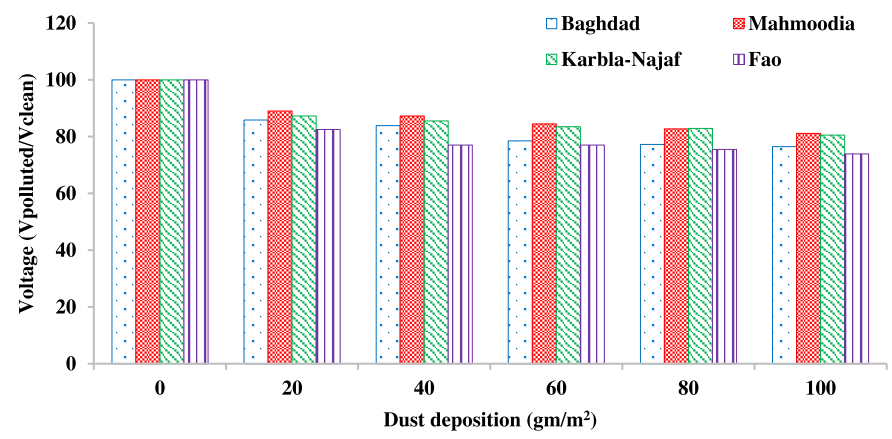

Fig. 5. Dust accumulation effect on $\mathrm{V}_{\text {polluted }} / \mathrm{V}_{\text {clean }}$ ratio.

Figure 5 shows the changes in the relation $\left(\mathrm{V}_{\text {polluted }} /\right.$ $\mathrm{V}_{\text {clean }}$ ) for the tested dust types. The results show a clear loss of voltage due to the accumulation of dust and this loss can be compensated by periodic cleaning of the solar module. The diagram shows that the most destructive type of dust is the Fao dust. Knowing the components of this dust from salt, PM and sulfur added to silica, then the establishment of power PV plants will inevitably require continuous cleaning every day and perhaps every two days. Cleaning such cells should first pay attention to the layer of salt, which is cleaned with a dry brush to mix the cell surface of the salts before cohesion and the formation of a salt layer on the surface and then using a sodium solution to get rid of PM as recommended in reference [12]. Mahmudiya dust is less likely to cause loss of voltages, so it is advisable to establish PV power plants in this area, especially since cleaning these cells will be periodically every two weeks or month without causing significant waste of energy. The Karbala-Najaf road area also did not cause significant losses in voltages. Voltage losses in Baghdad are obvious, higher than in Mahmoodia and Karbala-Najaf. Also, the most important pollutant to be wary of is PM, so it is advisable to perform periodic cleaning every two weeks at most using a dry brush and then a solution of sodium.

In the presence of losses in current and voltages, surely the losses of their product (power) will be significant. It is noted that the dust of Fao caused the highest losses followed by the dust of Baghdad, while the lowest losses were the share of dust Mahmoodia. Figure 6 reveals power

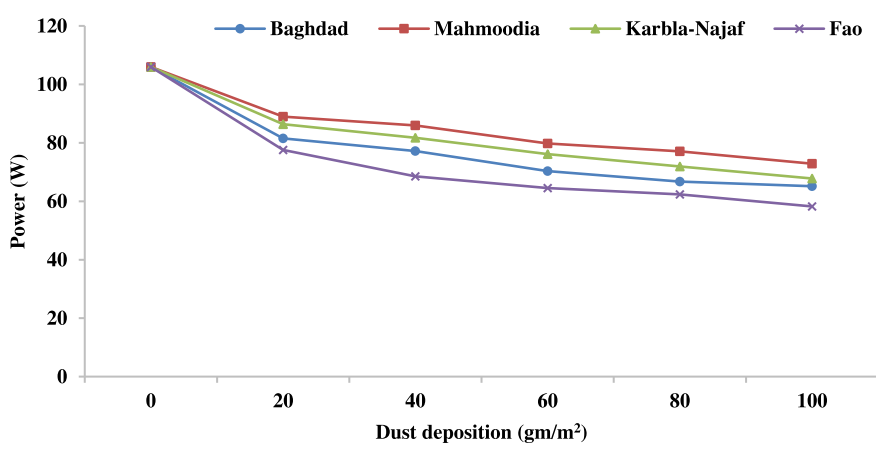

Fig. 6. Power reduction due to dust accumulation on PV surface for the tested dust types.

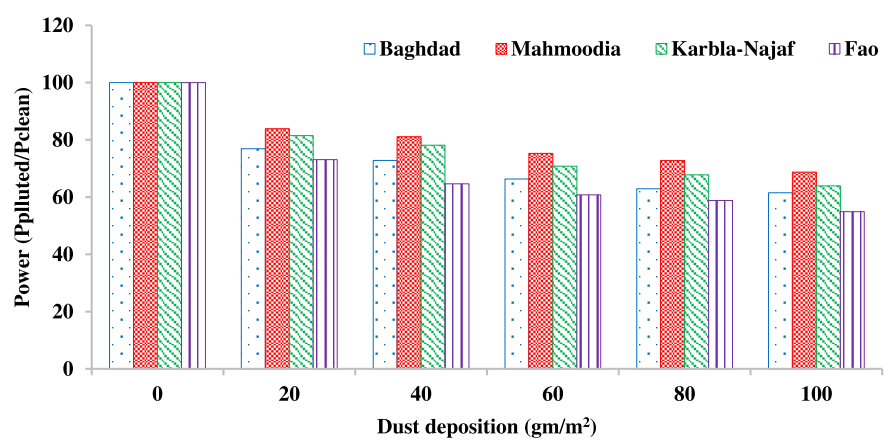

Fig. 7. Dust accumulation effect on $\mathrm{P}_{\text {polluted }} / \mathrm{P}_{\text {clean }}$ ratio.

losses due to dust depositions for the tested station: $38.50 \%, 31,12 \%, 36.01 \%, 45.06 \%$ for Baghdad, Mahmoodia, Karbla-Najaf and Fao stations, respectively, when dust was deposited from 0 to $100 \mathrm{~g} / \mathrm{m}^{2}$. This result shows a significant waste of generated power due to the dust accumulation and the need to minimize its effect by proper and periodic cleaning.

Figure 7 shows the $\left(\mathrm{P}_{\text {polluted }} / \mathrm{P}_{\text {clean }}\right)$ for the tested dust type deposition. The dust accumulated by only $20 \mathrm{~g} / \mathrm{m}^{2}$ caused power losses up to $23.10 \%, 16.10 \%, 18.52 \%$, and $26.90 \%$ for Baghdad, Mahmoodia, Karbla-Najaf and Fao stations, respectively. The components of dust particles play an important role in these losses as long as the rest of the weather effects are isolated. The bulk of the components of Iraqi dust in general are from nanoscale particles, and such particles have a detrimental effect even when deposited in small quantities due to its high surface area.

\section{Conclusion}

In this study, the effect of dust deposition and contaminants on PV module performance was investigated. Emphasis was placed on the impact of the components and the quality of the accumulated dust on the PV's current, voltage and power. Dust was collected from four different stations: Baghdad city, an agricultural area in Mahmoodia, Karbala-Najaf desert road, and Fao city adjacent to the Gulf and the Salt Lake. Examination of 
dust components found that a large amount of silica, which confirms its main source is the desert. Baghdad and Mahmoodia dust samples showed clear concentrations of minerals such as iron, aluminum, calcium, magnesium and other materials available in clay, silt, bentonite and muscovite. Baghdad and Fao dust samples also showed clear concentrations of particulate matter, lead and sulfur, confirming high levels of pollutants emitted from burning fossil fuels. Fao dust samples were found to have high concentrations of sodium and potassium chloride. By measuring the changes in current, voltages and power of a solar cell when accumulating the types of dust studied, it was found that the effect of this accumulation is significant, especially for the dust of the Fao and Baghdad. The results confirmed the need for periodic cleaning of cells in these areas and should be the period between cleaning and another not more than two days for FAO, while the rest of the areas are every two weeks. The study also confirmed that, based on the dust components, a dry brush and a sodium solution should be used for Baghdad and Al-Fao. Suffice it to use a dry brush and compressed water for the Mahmoodia and Karbala-Najaf areas.

\section{References}

1. P. Rivotti, M. Karatayev, Z.S. Mourão, N. Shah, M.L. Clarke, D.D. Konadu, Energy Strategy Rev. 24, 261-267 (2019)

2. H.M.S. Al-Maamary, H.A. Kazem, M.T. Chaichan, Renew. Sustain. Energy Rev. 76, 555-576 (2017)

3. H.M.S. Al-Maamary, H.A. Kazem, M.T. Chaichan, Renew. Sustain. Energy Rev. 75, 989-1007 (2017)

4. F. Manzano-Agugliaro, A. Alcayde, F. Montoya, A. ZapataSierra, C. Gil, Renew. Sustain. Energy Rev. 18, 134-143 (2013)

5. S.K. Gupta, P. Purohit, Renew. Sustain. Energy Rev. 22, 380-392 (2013)

6. V. Lo Brano, A. Orioli, G. Ciulla, A. Di Gangi, Solar Energy Mater. Solar Cells 94, 1358-1370 (2010)

7. H.A. Kazem, H.A.S. Al-Badi, A.S. Al Busaidi, M.T. Chaichan, Environ. Dev. Sustain. 19, 05 (2017)

8. A.H.A. Al-Waeli, K. Sopian, H.A. Kazem, M.T. Chaichan, Renew. Sustain. Energy Rev. 77, 109-130 (2017)

9. Z.A. Darwish, H.A. Kazem, K. Sopian, M.A. Al-Goul, H. Alawadhi, Renew. Sustain. Energy Rev. 41, 735-744 (2015)
10. J. Tanesab, D. Parlevliet, J. Whale, T. Urmee, T. Pryor, Sol. Energy, 120, 147-157 (2015)

11. M.T. Chaichan, H.A. Kazem, Generating Electricity Using Photovoltaic Solar Plants in Iraq (Springer, Berlin, 2017)

12. M.T. Chaichan, B.A. Mohammed, H.A. Kazem, Int. J. Sci. Eng. Res. 6, 04 (2015)

13. S. Pulipaka, F. Mani, R. Kumar, Sol. Energy 123, 116-126 (2016)

14. B. Weber, A. Quinones, R. Almanza, M.D. Duran, Energy Procedia 57, 99-108 (2014)

15. A.A. Hachicha, I. Al-Sawafta, D.B. Hamadou, Renew. Energy 143, 263-276 (2019)

16. E. Adıgüzel, E. Özer, A. Akgündogdu, A.E. Yılmaz, Sol. Energy 177, 690-702 (2019)

17. Z.A. Darwish, H.A. Kazem, K. Sopian, M. Alghoul, M.T. Chaichan, Int. J. Energ. Environ. 7, 04 (2013)

18. H.A. Kazem, M.T. Chaichan, Sol. Energy 139, 68-80 (2016)

19. K. Styszko, M. Jaszczur, J. Teneta, Q. Hassan, P. Burzynska, E. Marcinek, N. opian, L. Samek, Environ. Sci. Pollut. Res. 26, 09 (2019)

20. A.A. Hachicha, I. Al-Sawafta, Z. Said, Renew. Energy 141, 287-297 (2019)

21. L.L. Kazmerski, A.S.A. Diniz, C.B. Maia, M.M. Viana, S.C. Costa, P.P. Brito, C.D. Campos, L.V.M. Neto, S. de Morais Hanriot, L.R. de Oliveira Cruz, IEEE J. Photovolt 6, 03 (2016)

22. H.A. Kazem, M.T. Chaichan, Sol. Energy 187, 30-38 (2019)

23. W. Javed, Y. Wubulikasimu, B. Figgis, B. Guo, Sol. Energy 142, 123-135 (2017)

24. A.A. Kazem, M.T. Chaichan, H.A. Kazem, Renew. Sustain. Energy Rev. 37, 734-749 (2014)

25. M.T. Chaichan, H.A. Kazem, T.A. Abid, Environ. Develop. Sustain. 20, 02 (2018)

26. A.A. Al-Waeely, S.D. Salman, W.K. Abdol-Reza, M.T. Chaichan, H.A. Kazem, H.S.S. Al-Jibori, Int. J. Eng. Technol. 14, 02 (2014)

27. H. Lu, L. Lu, L.Z. Zhang, A. Pan, Energy Procedia 158, 879 $884(2019)$

28. M. Al-Addous, Z. Dalala, F. Alawneh, C.B. Class, Sol. Energy 194, 86-102 (2019)

29. A. Jha, P.P. Tripathy, Renew. Energy 135, 856-865 (2019)

30. T.S. Ustun, Y. Nakamura, J. Hashimoto, K. Otani, Renew. Energy 136, 159-178 (2019)

31. H.A. Kazem, M.T. Chaichan, A.H. Alwaeli, K. Mediterranean Green Buildings and Renewable Energy, Selected Papers from the World Renewable Energy Network's Med Green Forum 1 January 2017

Cite this article as: Miqdam T. Chaichan, Hussein A. Kazem, Ali H.A. Al-Waeli, Kamaruzzaman Sopian, The effect of dust components and contaminants on the performance of photovoltaic for the four regions in Iraq: a practical study, Renew. Energy Environ. Sustain. 5, 3 (2020) 